\title{
Latvijas medicīnas vēsture Baltijas zinātṇu vēstures konferencēs: 1958-2008
}

\author{
Arnis Vīksna
}

Apkopoti dati no konferenču tēžu krājumiem, bet par pirmajām divām konferencēm - pèc to programmām. Pavisam 23 Baltijas zinātṇu vēstures konferencēs nolasìti (pieteikti) 212 ziņojumi par Latvijas medicinas vēsturi (sk. tabulu).

Ziņojumus sagatavojis 121 autors. No mūžỉbai piepulcinātiem medicīnas vēsturniekiem biežāk referējuši Kārlis Arons (1933-2005) - 10, Maija Blumberga (1938-1994) - 5, Vilis Derums (1899-1988) - 8, Fjodors Grigorašs (1906-1984) 7, Solomons Magiḷnickis (1903-1990) - 4, Moisejs Suhodrevs (1901-1976) - 4 ziņojumi. Mūsdienu pētnieki: Māris Baltiņš - 5, Edīte Bērziņa - 5, Aija Dirbe - 9, Jūlijs Jākobsons - 10, Rita Kukaine - 7, Ruta Lindberga - 4, Alfreds Miltiņ̌̌ - 11, Vents Miltiňš - 4, Maija Pozemkovska (Anže) - 5, Valda Pundure - 5, Juris Salaks - 4, Jānis Stradiṇš - 6, Konstantins Vasiljjevs, sen. - 7, Konstantins Vasiljjevs, jun. - 4, Arnis Vìksna - 33 ziņojumi, u. c.

Paleopatologijai veltīti 7 ziņojumi (V. Derums), latviešu tautas medicīnai - 6 (K. Arons, Ādolfs Karnups, 1904-1973; Ausma Zviedre, 1942-1979), feodālisma laikmeta medicinai - 5 (A. Dirbe, Silvija Ķuze, 1921-1984; A. Zviedre u. c.), kapitālisma laikmeta medicinai - 8 (F. Grigorašs, K. Vasiḷjevs, sen., A. Vỉksna u. c.), padomju veselïbas aizsardzībai un medicinnai - 5 (F. Grigorašs, Vilhelms Kaṇeps, 1923-1993, u. c.).

Augstākajai medicīnas izglìtībai Latvijā veltīti 13 ziņojumi (K. Arons, M. Baltiņšs, Marija L̦ebedkova, Uldis Vikmanis, A. Vīksna u. c.), epidēmiju vēsturei - 4 (K. Vasiljevs, sen. u. c.). No medicinas disciplīnām pētnieku uzmanību vairāk saistījusi ķirurǵijas - 11 (Aleksandrs Bieziņš, 1897-1975, u. c.), dermatovenerologíjas - 11 (A. Miltiņ̌š, V. Miltiņ̌š), mikrobioloğijas un virusoloǵijas - 6 (J. Jākobsons, R. Kukaine), oftalmologijas - 7 (S. Magilninickis u. c.), anatomijas - 6 (R. Lindberga, V. Pundure u. c.), internās medicinas - 4 (Ilmārs Lazovskis, 1931-2003, u. c.), psihiatrijas - 6 (Imants Eglïtis, 1938-1997; Vladimirs Kuznecovs u. c.), rentgenolog̣ijas vēsture - 3 (Jānis Lediṇš, 1900-1989; Jevgeniijs Nemiro) referāti u. tml. 


\section{Tabula. Latvijas medicīnas vēsture Baltijas zinātṇu vēstures konferencēs}

\begin{tabular}{|c|c|c|c|}
\hline Konference & Gads un datums & Vieta & Ziņojumi \\
\hline I & $1958,6 .-7 . \mathrm{VI}$ & Rīga & 3 \\
\hline II & $1959,20 .-21 . \mathrm{I}$ & Tartu & 2 \\
\hline III & 1959, 30. XI-2. XII & Viḷna, Kauṇa & 6 \\
\hline IV & 1962, 27.-29. XI & Rìga & 11 \\
\hline $\mathrm{V}$ & $1964,18 .-21 . \mathrm{VI}$ & Tartu & 4 \\
\hline VI & 1965, 26.-27. X & Vil̦na & 11 \\
\hline VII & 1968, 11.-13. XII & Rīga & 12 \\
\hline VIII & $1970,1 .-3 . \mathrm{VII}$ & Tartu & 5 \\
\hline IX & 1972, 2.-4. XI & Viḷ,na & 9 \\
\hline $\mathrm{X}$ & 1975, 21.-23. IV & Rīga, Jelgava & 3 \\
\hline $\mathrm{XI}$ & $1977,18 .-21 . X$ & Tallina, Tartu & 11 \\
\hline XII & $1979,23 .-26 . X$ & Viḷna & 14 \\
\hline XIII & 1982, 17.-19. XI & Tartu & 3 \\
\hline XIV & 1985, 25.-28. XI & Jūrmala, Rīga & 18 \\
\hline $\mathrm{XV}$ & 1987, 29. IX-1. X & Riga & 16 \\
\hline XVI & 1991, 4.-6.X & Vil̦na & 6 \\
\hline XVII & 1993, 4.-6. X & Tartu & 5 \\
\hline XVIII & 1996, 17.-19. I & Rīga & 23 \\
\hline XIX & $1999,15 .-17 . \mathrm{I}$ & Vil̦na, Kauṇa & 5 \\
\hline $\mathrm{XX}$ & $2001,30 .-31 . \mathrm{I}$ & Tartu & 6 \\
\hline XXI & $2003,13 .-15 . X$ & Rīga & 16 \\
\hline XXII & 2006, 5.-6. X & Vil̦ņa, Kauņa & 8 \\
\hline XXIII & $2008,9 .-10 . X$ & Rìga & 15 \\
\hline Kopā & & & 212 \\
\hline
\end{tabular}

No medicīnas iestādēm visplašāko ievērību guvis Paula Stradiṇa Medicīnas vēstures muzejs, kam veltiti 20 ziņojumi (E. Bērziņa, Herta Hanzena, 1909-1972; M. L̦ebedkova u. c.), seko Rīgas 1. slimnīca ar 7 un Rīgas Kara hospitālis ar 2 ziņojumiem.

No ievērojamām personībām visvairāk referātu veltīts Paulam Stradiṇam (1896-1958) - 12, seko Oto Hūns (1764-1832) - 5, Augusts Kirhenšteins (18721963) - 4, A. Bieziņš - 3, Jēkabs Alksnis (1870-1957), Gastons Bakmanis (18831964), Pēteris Sniķers (1875-1944) - pa 2, u. c.

Starpvalstu un starpaugstskolu medicīnas zinātniskie sakari aplūkoti 16 referātos, visvairāk par Tērbatas Universitāti un Latviju (A. Vỉksna u. c.), kam seko Viḷnas un Maskavas universitātes, kā arī Pēterburgas Kara medicīnas akadēmija. 
Vēl 9 referātos aplūkoti medicīnas historiogrāfijas jautājumi un 3 referātos medicinas pieminekḷi (A. Vỉksna u. c.).

Konferences bija izdevīgs poligons jauno spēku ienākšanā medicīnas vēstures pètījumos; tās sekmēja pieredzes apmainu un koleǵiālas attiecības pētnieku vidū. Tajās tikpat kā nav aplūkoti metodikas jautājumi. Nav veikti arī lieli starpvalstu sadarbības projekti. Tomēr stimulējoši pozitīvā gaisotne ir saglabājusies, un tas palïdz katra pētnieka ikdienas darbā.

\section{Literatūra}

I Первое межреспубликанское совещание по проблеме изучения истории естественных наук и медицины Прибалтики.//Из истории медиииныл. Т. 2. Рига: 1959. с. 309-313.

1. Васильев К.Г. Эпидемии и противоэпидемические мероприятия в Латвии в XIX веке.//I, с. 310.

2. Круминь О. О состоянии и перспективах развития Рижского музея истории медицины.//I, с. 310.

3. Грикис В. Об экспозиции материалов по истории медицины Прибалтики.//I, .310.

II Второе межреспубликанское совещание по истории науки в Прибалтике.//Из истории медицины. Т. 2. Рига: 1959. с. 315-319.

4. Чуринкис В. Академик П. И. Страдынь и его музей истории медицины// II, c. 315.

5. Страдынь Я.П. Д. Г. Гриндель - первый ученый латышской национальности//II, с. 316.

III III межреспубликанская конферениия по вопросам истории естествознания и техники в Прибалтике. Тезисы докладов. Вильнюс: 1959. $106 \mathrm{c}$.

6. Васильев К.Г. Основные направления и этапы в истории развития противоэпидемических мероприятий в России и Латвии в XVII-XIX веках,// III, c. 19-22.

7. Герке П.Я. Роль академика Павла Ивановича Страдыня в развитии историко-медицинской науки Латвии.//III, с. 25.

8. Григораш Ф. Ф. Основные этапы развития здравоохранения в Латвийской ССР.//III, с. 26-29.

9. Карнупс А. Вопросы доисторической гигиены и медицины в экспозиции Музея истории медицины им. П. Страдыня.//III, с. 48-51.

10. Халдин А.К., Реморов В.Н. К 250-летию Рижского военного госпиталя.// III, c. 89-90. 
11. Магильницкий С.Г. Офтальмология первобытно-общинного строя//III, с. 104.

IV Наука в Прибалтике в XVIII-начале XX века. Тезисы докладов IV межреспубликанской конференции по истории науки в Прибалтике. Рига: 1962. 232 c.

12. Герке П.Я., Васильев К.Г. Основные направления исследований в области истории медицины и здравоохранения в Латвийской CCP.//IV, c. $11-14$.

13. Ханзен Г.А. Музей истории медицины им. П. Страдыня и перспективы его дальнейшего развития.//IV, с. 14-17.

14. Арон К.Я. Развитие высшего медицинского образования в Латвии.//IV, c. $112-114$.

15. Григораш Ф.Ф. К вопросу о развитии медицинской науки в Латвии.// IV, c. 114-117.

16. Биезинь А.П. О роли Тартуского университета в подготовке латышских врачей-хирургов.//IV, с. 122-123.

17. Реморов В.Н., Халдин А.К. Военные госпитали русской армии в Прибалтике.//IV, с. 147-149.

18. Страдынь Н.Ф., Страдынь Я.П. А. А. Лозинский - крупнейший отечественный бальнеолог.//IV, с. 150-154.

19. Сочнева 3.Г. Основные этапы развития психиатрической помощи в Латвии в связи с развитием психиатрии в центральной России (конец XVIII - начало XX вв.).//IV, с. 154-156.

20. Магильницкий С.Г. Развитие офтальмологии в Латвии во второй половине XIX в.//IV, с. 160-161.

21. Васильев К.Г. Историко-эпидемиологический анализ инфекционной заболеваемости в Латвии в XIX и первой половине XX столетия.//IV, c. 171-172.

22. Богачева Р.П. Санитарно-эпидемическая обстановка в Риге в период с 1915 по 1920 г.//IV, с. 176-177.

V Материаль V конференции по истории науки в Прибалтике. Тарту: 1964. $198 \mathrm{c}$.

23. Григораш Ф.Ф., Арон К.Я. Вопросы периодизации в историкомедицинских исследованиях Советской Латвии.//V, с. 82-86.

24. Дэрумс В.Я. О травмах костей и народном врачевании по материалам археологических раскопок в Прибалтике.//V, с. 89-92.

25. Суходрев М.Б. Врачебная, научно-педагогическая и общественная деятельность в Прибалтике проф. Д.Г. Балка.//V, с. 156-158. 
26. Ханзен Г.А. История медицины и здравоохранения Прибалтики в экспозициях Музея истории медицины им. П. Страдыня.//V, с. 167-170.

VI Материаль VI-ой конференции по истории науки в Прибалтике. Вильнюс: 1965. $275 \mathrm{c}$.

27. Арон К.Я. Латышская народная медицина и вопросы медико-антирелигиозной пропаганды.//VI, с. 133-135.

28. Бэрг Э. Бани старой Риги до конца XV века.//VI, с. 140-142.

29. Биезинь А.П. К истории ортопедии в Латвийской ССР.//VI, c. 142-144.

30. Васильев К.Г. Исторический опыт борьбы с оспой в Прибалтике.//VI, с. 156-157.

31. Васильев К.Г., Васильева Н.И. Новые материалы для биографии доктора Оттона Гуна.//VI, с. 157-158.

32. Герке П.Я. Становление и развитие Музея истории медицины им. П. И. Страдыня и его роль в развитии историко-медицинской науки в Латвии.//VI, с. 163-164.

33. Григораш Ф.Ф., Арон К.Я. К истории специализации и усовершенствования врачей в Латвии.//VI, с. 166-168.

34. Дирбе А. О распространении вакцинации в Видземе.//VI, с. 174-175.

35. Дэрумс В.Я. О динамике физического состояния жителей Прибалтики в историческом аспекте.//VI, с. 176-178.

36. Канеп В.В. Развитие медицинской науки в Латвийской CCP.//VI, с. 196198.

37. Лебедькова М.С. К истории развития госпитальной хирургической клиники в Латвии.//VI, с. 220-223.

VII Научные связи Прибалтики в XVIII-X веках. Материалы VII прибалтийской конференции по истории науки. Рига: 1968. 266 с.

38. Ханзен Г.А., Блумберга М. Музей истории медицины им. П. Страдыня и отображение в его экспозициях истории медицины Латвии.//VII, с. 159-165.

39. Карнуп А.Я. Народная медицина и гигиена раннефеодальной эпохи на территории Латвийской ССР по материалам археологических раскопок.//VII, с. 165-167.

40. Апсе Р.Л. Первые статьи медицинского содержания в латышских периодических изданиях (1768-1855 гг.).//VII, с. 173-175.

41. Дэрумс В.Я. Влияние рационалистических идей России и Германии на развитие медицины в Прибалтике в XVIII-XIX веках.//VII, с. 176181.

42. Дирбе А.В. Рижский врач Отто Гун - популяризатор вакцинации в России.//VII, с. 183-185. 
43. Брежинский Г.Я. Взгляды профессора М. Б. Зиле на бронхиальную астму.//VII, с. 213-215.

44. Биезинь А.П. Развитие хирургии на территории Латвийской ССР в XIX-XX веках.//VII, с. 215-218.

45. Григораш Ф.Ф., Альтшулер Б.Э. Развитие ортопедии и травматологии в Латвии в первой половине XX века.//VII, с. 218-223.

46. Арон К.Я. Роль Петербургской Военно-медицинской академии в развитии медицинской науки в Латвии.//VII, с. 223-226.

47. Страдынь Я.П. Научные связи П. И. Страдыня в 1924-1940 гг.//VII, с. 226-229.

48. Магильницкий С.Г. Польский офтальмолог Казимир Ноишевский в Даугавпилсе.//VII, c. 237-242.

49. Липовецкая Л.Л. Первые женщины-медики в Латвии.//VII, с. 244-245.

\section{VIII Материаль VIII конференции по истории науки в Прибалтике.} Тарту: $1970.181 \mathrm{c}$.

50. Виксна А.А. О медиках-новотеченцах в девяностых годах прошлого века в Латвии.//VIII, с. 108-109.

51. Дирбе А. В. О. Гун - ранний поборник улучшения преподавания психиатрии и обслуживания психических больных в Прибалтике.//VIII, с. 109-110.

52. Дэрумс В.Я. О развитии и задачах палеопатологии человека в Прибалтике.//VIII, с. 110-113.

53. Кукайн Р., Якобсон Ю. Преемственность научных традиций в микробиологии в Латвии.//VIII, с. 131-132.

54. Хнох Л.И., Суходрев М.Б. А. Ф. Лиепукалн - продолжатель научных традиций медицинских школ Москвы и Тарту и его роль в развитии современной хирургии в Латвии.//VIII, с. 151-153.

IX Материаль IX межреспубликанской конференции по истории естествознания и техники в Прибалтике. Вильнюс: 1972. 244 с.

55. Арон К.Я. Этапы и закономерности развития высшего медицинского образования и медицинской науки в Латвийской ССР.//IX, c. 4-5.

56. Виксна А.А. Об участии медицинских работников в революции 19051907 гг. в Латвии.//IX, с. 28-30.

57. Виксна А.А. О первых случаях применения эфирного и хлороформного наркоза в Латвии.//IX, с. 30.

58. Дирбе А. К вопросу об организации обучения акушерок в Курляндской губернии в первой половине XIX в.//IX, с. 60-61.

59. Дэрумс В.Я. Палеопатологические исследования в Советском союзе.// IX, c. 63-65.

60. Звиедре А. Вопросы народного здоровья в трудах крупнейших латышских писателей-реалистов XIX в.//IX, с. 68-70. 
61. Карнуп А.Я. Некоторые типы народно-медицинских инструментов V-XIII вв. на территории Латвийской ССР в сравнение с античными медицинскими инструментами.//IX, c. 93-94.

62. Кюзе С. Медицинская терминология в литературных источниках XVII в.//IX, c. 115-116.

63. Суходрев М.Б. Идеи академика П. И. Страдыня в развитии физиотерапии и курортов в Латвийской ССР.//IX, с. 191-192.

Х История науки и науковедение. Х прибалтийская конференция по истории науки. Тезисы докладов. Рига: $1975.211 \mathrm{c.}$

64. Дирбе А.В., Виксна А.А. Врачи - воспитанники Петровской академии.//X, c. $113-115$.

65. Суходрев М.Б. Роль К. Х. Шимана в изучении курорта Балдоне.//Х, с. 116-119.

66. Кукайн Р.А., Якобсон Ю.О. Проблемы инфекции в медицинских диссертационных работах ученых Прибалтики XVIII века.//X, с. 179-180.

XI Вопросы медицины и биологии Прибалтики. Тезисы докладов ХІ прибалтийской конференции по истории науки и техники. Тарту: 1977. $208 \mathrm{c}$.

67. Дэрумс В.Я. О первоисточниках истории хирургии в Прибалтике.//XI, c. $18-20$.

68. Виксна А.А. К изучению истории медицины Латгалии (1772-1917).//XI, c. 20-24.

69. Григораш Ф.Ф., Виксна А.А. Врачи-уроженцы Латвии - участники Великой октябрьской социалистической революции.//XI, с. 30-34.

70. Милтиньш А.П. Венерические заболевания и венерология в буржуазной Латвии.//XI, с. 71-77.

71. Звиедре А.К. Предметы личной гигиены эпохи раннего феодализма (X-XII вв.) на территории Латвийской ССР.//XI, с. 77-80.

72. Магильницкий С.Г. Первые в России рентгеновские снимки инородных тел глаза.//XI, с. 81-83.

73. Кукайн Р.А., Индулен М.К., Якобсон Ю.О. Идеи А. М. Кирхенштейна и современная вирусология.//XI, с. 99-101.

74. Шамардин Б.М., Калнин В. В., Виксна А. А. О деятельности в области медицины в Густавианской и Густаво-Каролинской академиях.//XI, с. 104-109.

75. Виксна А.А. О первых латышских профессорах-медиках - воспитанниках отечественных медицинских школ.//XI, с. 120-123.

76. Блумберга М.В. Связи основоположника детской хирургии в Латвии А. П. Биезиня с Тартуской научной школой хирургов.//XI, с. 159-161.

77. Дирбе А.В. История коллекции И. И. Мечникова.//XI, с. 188-190. 
XII Роль Вильнюсского университета в развитиии науки. Тезисы докладов XII прибалтийской конференции по истории науки и техники. Вильнюс: 1979. $183 \mathrm{c.}$

78. Виксна А.А. Врачи Латгалии - воспитанники Вильнюсской высшей медицинской школы XVIII-XIX веков.//XII, с. 87-89.

79. Лебедькова М.С., Дирбе А.В., Арон К.Я., Виксна А.А. Из истории латвийско-литовских контактов в области медицины.//XII, с. 90-92.

80. Блумберга М.В. Некоторые данные о связях курляндских врачей с Вильнюсским университетом в начале XIX века.//XII, с. 100-102.

ХІІа Вопросымедицины и биологии Прибалтики. Тезисыдокладов ХІІ прибалтийской конференции по истории науки и техники. Вильнюс: 1979.76 с.

81. Кукайн Р.А., Гривинь П.П., Якобсон Ю.О. А. М. Кирхенштейн - основатель школы микробиологов в Латвии.//XIIa, с. 8-9.

82. Григораш Ф.Ф., Цудечкис Л.М. Вопросы борьбы с алкоголизмом в научном наследии А. Кирхенштейна и Я. Асара.//XIIa, c. 9-11.

83. Дэрумс В.Я. Антропометрические и рентгеноморфологические параллели в костях нижних конечностей жителей Латвии от эпохи неолита до наших дней.//XIIa, c. 14-17.

84. Сеглениеце К.Б., Красноперка Л.И. Динамика физического развития детей в условиях Латвийской ССР за 50 лет.//ХІІа, с. 17-20.

85. Виксна А.А. Историко-медицинские памятники Латвии.//XIIa, с. 20-22.

86. Пундуре В.Я. Внимание рижских врачей к охране окружающей среды в XVII-XIX вв.//XIIa, с. 22-25.

87. Звиедре-Ферстере А.К. Спорные вопросы в истории создания первых рижских госпиталей.//ХIIa, с. 35-38.

88. Мельник В.И. К вопросу о гигиенических исследованиях в Латвии.//XIIa, c. $38-40$.

89. Магильницкий С.Г. Конференции офтальмологов Прибалтики в 19281938 гг.//ХIIa, с. 50-52.

90. Якобсон Ю.О., Кукайн Р.А. Организация исследований в области микробиологии и вирусологии.//ХІІа, с. 52-54.

91. Милтиньш А.П. Анализ вензаболеваемости в буржуазной Прибалтике.// XIIa, c. 54-56.

XIII Тартуский государственный университет. История развития, подготовка кадров, научные исследования. І. Общественные науки. Тезисы докладов Всесоюзной (XIII прибалтийской) конференции по истории науки, посвященной 350-летию Тартуского государственного университета. Тарту: 1982. 208 с.

92. Виксна А.А. Латышские професора - воспитанники Тартуского (Дерптского, Юрьевского) университета.//XIII, с. 138-144. 
ХІІІа Тартуский государственньй университет. История развития, подготовка кадров, научные исследования. III. Медицина, биология, физическая культура. Тезисы докладов Всесоюзной (XIII прибалтийской) конференции по истории науки, посвященной 350-летию Тартуского государственного университета. Тарту: 1982. 273 с.

93. Васильев К.К. Судьба библиотеки доктора О. Гуна.//ХІІІа, с. 179-181.

94. Кукайн Р.А., Якобсон Ю.О. Влияние Тартуского университета на развитие микробиологии в Латвии.//ХIIIa, с. 201-206.

XIV Становление науки и научных коллективов Прибалтики. Тезисы докладов XIV прибалтийской конференции по истории науки. Рига: 1985. $348 \mathrm{c}$.

95. Канеп В.В., Арон К.Я. Становление научно-медицинских школ в Латвийской CCP.//XIV, с. 220-221.

96. Виксна А. Тартуский университет и возникновение научно-медицинских школ в Латвии.//XIV, с. 231-233.

97. Лазовскис И.Р. Основные направления терапевтических школ в Латвии.//XIV, с. 236-237.

98. Пундуре В.Я. Латвийские научные школы анатомов.//XIV, с. 238-239.

99. Янсон Х.А. Становление биомеханики в Латвии.//XIV, с. 244-247.

100. Магильницкий С.Г. Профессор Янис Юьевич Руберт и латвийская школа офтальмологов.//XIV, с. 248-249.

101. Лединьш Я.Д. Становление и развитие рентгенологии как научной дисциплины в Латвии (1896-1940 гг.).//XIV, с. 250-251.

102. Милтиньш А.П. Основные этапы развития дерматовенерологии в Латвии.//XIV, с. 252-253.

103. Эглитис И.Р. Научные коллективы психиатров Латвии с конца XIX в. до наших дней.//XIV, с. 256-257.

104. Блумберга M.В. Карл Барон и научная школа латвийских стоматологов.//XIV, с. 259-260.

105. Пийола С.У. К генеалогии И. Э. О. Шмидеберга.//XIV, с. 266-268.

106. Якобсон Ю.О., Кукайн Р.А. Этапы и основные направления развития микробиологии и вирусологии в Латвии.//XIV, с. 276-277.

107. Дедюлин В.И. Первые исследования по физиологии и гигиене труда на подводных лодках русского флота.//XIV, с. 282.

108. Дэрумс В.Я. Патологоанатомическая основа легенды о кривом барине.// XIV, c. 312-313.

109. Милтиньш А.П. Социально-этические и медицинские аспекты в латышском фольклоре.//XIV, с. 319-320.

110. Виксна А. Памятники медицины Латвии//XIV, 335-336.

111. Якобсон Ю.О. Материалы по созданию музея А. М. Кирхенштейна.// $\mathrm{XIV}$, c. 341-342. 
112. Эглитис И.Р. Музей истории психиатрии при Елгавской психиатрической больнице и коллекция А. Ф. Лаксберга.//XIV, с. 343-344.

XV Проблемы развития науки и техники Прибалтики. Тезисы докладов XV прибалтийской конференции по истории науки и техники. Ч. 1. Рига: 1987. 236 с.

113. Пундуре В.Я. Рижский анатомикум как памятник науки.//XV, с. 227-228.

114. Виксна А. А. Места захоронений видных медицинских работников Латвии.//XV, с. 229-231.

ХVа Проблемы развития науки и техники Прибалтики. Тезисы докладов XV прибалтийской конференции по истории науки и техники. Ч. 2. Рига: 1987.183 с.

115. Арон К.Я., Лапиньш У.П. П. Я. Страдынь и вопросы медицинской деонтологии.//XVa, с. 76-77.

116. Эглитис И.Р., Страздыньш Я.К. История развития движения за трезвость в Латвии.//XVa, c. 78-79.

117. Милтиньш А.П. Научные исследования и преподавание дерматовенерологии в высших школах Прибалтики.//XVa, с. 80-81.

118. Милтиньш А.П. Рижский врач Август Гакен - изобретатель уретроскопа.//XVa, с. 88-89.

119. Албина И.Я. Состояние онкологической помощи в Латвии (19201940 гг.).//XVa, c. 90-91.

120. Калвиньш И.Я., Симхович Б.З., Лукевиц Э.Я. Развитие исследований по изучению биологической роли карнитина и создание на их основе новых лекарственных средств.//XVa, c. 106-107.

121. Лебедькова М.С. Проблемы историко-медицинских музеев.//XVa, c.112-113.

122. Рудака И.К. Основные направления комплектования фондов по истории медицины и фармации Прибалтики Музея истории медицины им. П. Страдыня (1975-1985).//XVa, c. 117-118.

123. Кронитис Э.А., Берзиня Э.В. Отражение научно-технического прогресса в здравоохранении в фондовых коллекциях Музея истории медицины им. П. Страдыня.//XVa, с. 119-120.

124. Блумберга М.В. Инструменты для экстракции зубных корней конца XIX и первой половины XX века из коллекции Музея истории медицины им. П. Страдыня.//XVa, с. 123-124.

125. Литовник И.Ф., Вигдорчик М.Ж. Коллекция изданий медицинского и аптекарского законодательства XVI-XVIII в.в. в Музее истории медицины имени П. Страдыня.//XVa, с. 127-128.

126. Виксна А. Неопубликованные материалы П. И. Страдыня.//XVa, с. 129-130. 
127. Страдынь Я.П. О научном архиве Паула Страдыня.//XVa, с. 131-132.

128. Якобсон Ю.О. Материалы о А. М. Кирхенштейне в различных архивах и музейных фондах.//XVa, с. 133-134.

XVI Fragments of the history of science in the Baltic states. Abstract of the 16th Baltic conference of history of science, II. Vilnius, Kaunas: 1991. 63 p.

129. Берзиня Э., Дирбе А. Сотрудничество обществ Красного Креста прибалтийских стран в двадцатые-тридцатые годы.//XVI, с. 6.

130. Блумберга М. Профессор Е. Алкснис в контексте прибалтийской хирургии.//XVI, с. 7.

131. Lazovskis I. The synthetic way of thinking in Latvian medicine and its connection with the European medical schools.//XVI, p. 24.

132. Miltinšs A. Organization of the chair of dermatovenerology and their founders in Lithuania, Latvia and Estonia.//XVI, p. 30.

133. Сюдикас В., Виксна А., Пундуре В. Некоторые данные о сотрудничестве медиков Литвы и Латвии в период между двумя мировыми войнами.// XVI, c. 43.

134. Слайдынь Я.А., Маровский А.Я. Исследования профессора П. И. Страдыня о нарушениях артериального кровообращения конечностей и их последующее использование в клинике.//XVI, с. 44.

XVII 17th Baltic conference on history of science: Baltic science between the west and the east. Tartu: $1993.120 \mathrm{p}$.

135. Lindberga R. Prof. Gaston Victor Backman und die schwedisch-lettischen Kontakte.//XVII, p. 77-78.

136. Fersters V. Scientific mission abroad by profesor Alexander Bieziņš.//XVII, p. 84-85.

137. Анже М., Балтыньш М., Виксна А. Заведующие кафедрами медицинского факультета Латвийского университета во время второй мировой войны.//XVII, с. 89-91.

138. Милтиньш А. Влияние Востока и Запада на развитие дерматовенерологии Латвии.//XVII, с. 96-98.

139. Калнин В., Сюдикас В., Виксна А. О сотрудничестве медиков Эстонии, Латвии и Литвы в 1920-1940 гг.//XVII, с. 103-105.

XVIII Theses historiae scientiarium Baltica, II. Riga: 1996. 128 p.

140. Anže M. Profesors Jēkabs Alksnis kā tautas medicīnas pētnieks.//XVIII, 16. lpp.

141. Arons K. E.., Viksna A. Thesis's scientific degree in the history of medicine.// XVIII, p. 17-18.

142. Бизюлявичюс С. Академик П. Страдынь в моих воспоминаниях.//XVIII, c. $19-20$. 
143. Fersters V. Profesors Aleksandrs Bieziṇš kā medicīnas vēsturnieks.//XVIII, 23-24. lpp.

144. Jākobsons J. Latvijas mikrobiologi laika gaitā. Amatieru devums mikrobiolog̣ijas vēstures izpētē.//XVIII, 34-35. lpp.

145. Калнин В., Виксна А. Наследие Исидора Бренсона.//XVIII, с. 37-38.

146. Виксна А. П. Страдынь и Латвийское научное общество историков медицины Калнин В., Виксна А. Наследие Исидора Бренсона.//XVIII, с. 50-51.

147. Vipmanis V. Oftalmologijas vēsturnieks Solomons Magiḷnickis.//XVIII, 52-53. lpp.

148. Ančupāne I. Sievietes skaistuma izjūta latviešu tautasdziesmās.//XVIII, 54-55. lpp.

149. Baltiņš M. Latvijas Universitātes Medicīnas fakultātes goda doktori.//XVIII, 62. lpp.

150. Baltiņ̌̌ M. Latvijas Universitātes Medicinnas fakultātes historiogrāfija.//XVIII, 63-64. lpp.

151. Dālmane A. Prof. K. Bogojavḷenska devums Latvijas augstskolu pedagogijā un zinātnē.//XVIII, 69-70. lpp.

152. Lindberga R., Raubiško B. Tautas dzīvā spēka pētišanas institūta zinātniskā darbïba.//XVIII, 71-72. lpp.

153. Mētra M., Lūkina R. Kārlis Balodis - izcilais latviešu oftalmologs.//XVIII, 75. lpp.

154. Милтиньш А. Профессор Петерис Сникерс - коллекционер и меценат.//XVIII, с. 76-77.

155. Miltiňš V. Die Entwicklung der Ideen von Paul Ehrlich im Lettland.//XVIII, S. 78-79.

156. Miltiņš V. Professor Pēteris Sniķeris und Pauls Stradiņš - die Gestalter der medizinischen Hochschule im Lettland.//XVIII, S. 80-82.

157. Nemiro J. Latvijas rentgenologija uz simtgades sliekšña.//XVIII, 84-85. lpp.

158. Ozoliņš P. Cilvēka un dzīvnieku fiziolog̣ija Latvijā.//XVIII, 86-87. lpp.

159. Pilmane M., Bērziņš U. Pasaules ievērojamākie morfologi Latvijā.//XVIII, 89-90. lpp.

160. Rezebergs I. Dermatovenerologija neatkarīgajā Latvijā un okupācijas režīmos lielvalstu savienībā.//XVIII, 94-95. lpp.

161. Slaidiņš J. Kārlis Kasparsons - pirmais Latvijas izglīīibas ministrs.//XVIII, 98-99. lpp.

162. Vatere E. Ebreju mediḳi Latvijā.//XVIII, 108. lpp.

XIX Abstracts of XIXth Baltic conference on the history of science, II. Vilnius, Kaunas: $1999.67 \mathrm{p}$.

163. Miltiņš V., Miltiņš A. Investigations of Latvian scientists of tuberculine.// XIX, p. 30-31. 
164. Vasilyev K. K. Medical emigration from Russia in the Baltic states in 19171922 years.//XIX, p. 51-52.

165. Vetra J., Lindberga R. Origin, progress and perspectives of the scientific activities of Latvian anthropologists.//XIX, p. 56-57.

166. Vìksna A. Establishment of the Riga medical institute.//XIX, p. 58.

167. Viksna A. History of medicine during the process of Latvia's rebirth.//XIX, p. 58-59.

$\mathrm{XX}$ Historiae scientiarum Baltica. Abstracts of XX Baltic conference on the history of science. Tartu: 2001. $157 \mathrm{p}$.

168. Викманис У., Виксна А. Выделение медицинского факультета из состава Латвийского государственного университета (1941-1950 гг.).// XX, c. 118-119.

169. Stradiñš J., Cēbere D. An attempt to found a medical academy in Riga in 1910.//XX, p. 119-121.

170. Baltiňš M. Dr. med. degree of the University of Latvia between two world wars.//XX, p. 127-128

171. Pundure V. Die Ärzte von Riga - Initiatoren der Begründung des Sanitätskomitees in Riga im 19. Jh.//XX, S. 135-136.

172. Salaks J. Oncology prevention in free and occupied Latvia.//XX, p. 136137.

173. Savenko S., Drača N. Holland books in the collection of Paul Stradiñ̌s Museum of the History of Medicine in Riga.//XX, p. 155-156.

XXI Science, higher education, technologies, medicine, humanities in the Baltics - past and present. Abstracts of the 21 st international Baltic conference on the history of science. Riga: 2003. $266 \mathrm{p}$.

174. Ančupāne I., Kolontaja I., Miltiņš V., Miltiņš A., Žileviča A. Uroǵenitālo slimību diagnostikas pilnveidošana Latvijā laika gaitā.//XXI, 217. lpp.

175. Anšelevičs J. Interno slimìbu klīnika Rỉgas 1. slimnīcā 20. gadsimta otrajā pusē.//XXI, 219-220. lpp.

176. Bērziña E., Dirbe A. Oto Hūna "Rīgas pilsētas medicīniski topogrāfiskais apraksts ar ārsta vērojumu pielikumu" kā medicīnas vēstures avots.//XXI, 221. lpp.

177. Гордюшина В. Профессор Роман Адельгейм и географическая патология в Латвии.//XXI, с. 225-226.

178. Lange J. R. Ķirurg̣ijas sākums un attīstība Rīgas 1. slimnīcā (1803-1920).// XXI, 237-238. lpp.

179. Lindberga R. Der weltberühmter schwedischer Professor Gaston Victor Backman und seine Tätigkeit in Lettland.//XXI, S. 239-230.

180. Mihelsons M. Latvijas Universitātes ḳirurğijas klīnikas Rīgas 1. Slimnīcā.// XXI, 243-245. lpp. 
181. Mihelsons M., Pavārs A. Ķirurǵijas klīnika Rīgas 1. slimnīcā mūsdienās.// XXI, 245-246. lpp.

182. N̦ikitins A., Upmane J. Rīgas 1. slimnīcas k̦irurǵijas klīnika pēckara laikā.// XXI, 247-248. lpp.

183. Паварс А., Викманис У., Виксна А. Рижская 1-я городская больница и развитие медицины в Латвии.//XXI, с. 249-250.

184. Pille A., Tankler H., Roostar L. The connections of Tartu university surgerons to Latvia in the 20th century.//XXI, p. 251.

185. Pozemkovska M., Viksna A. Half a century of the Latvian society of medical historians.//XXI, p. 252.

186. Савенко С., Виксна А. Медицинские музеи Латвии.//XXI, с. 254-255.

187. Васильев К., Васильев Ю. У истоков больничного дела в Риге.//XXI, c. $259-260$.

188. Veinberga T. Dzemdībpalīdzība latviešu folklorā.//XXI, 262-263. lpp.

189. Verbovenko J. Kardiologiija Rīgas 1. slimnīcà.//XXI, 264-265. lpp.

XXII Historiae scientiarum Baltica. XXII Baltic conference on the history of science. Programme of the section on the history of medicine, pharmacy and veterinary and abstracts, II. Vilnius, Kaunas: 2006.139 p.

190. Baltiņš M., Viksna A. Reprints of Latvian books on medicine.//XXII, p. 25-26.

191. Bērziña E., Pozemkovska M., Salaks J. Problems with disabled people in the Republic of Latvia after the first world war.//XXII, p. 29.

192. Dalmane A., Kalnina M., Korolova O. Develpoment of citology in Latvia (1930-1973).//XXII, p. 31-32.

193. Kuznecovs V. The early period of Latvian psychiatry: legal aspect.//XXII, p. 71-72.

194. Plavina L., Knipse G. Medical services in Latvian armed forces during the first world war.//XXII, p. 104-105.

195. Savenko S., Viksna A. The medical faculty of Moscow university and Latvia.// XXII, p. 111-112.

196. Vasylyev K. K. P. I. Stradyn's historico-medical conception as a basis for studying the Baltic countries' history of medicine.//XXII, p. 122-123.

197. Vikmanis U., Viksna A. Professor Fjodor Grigorash and interpretation of the history of medicine of Latvia.//XXII, p. 128-129.

XXIII Nova Miscellanea Historiae Scientiarum Baltica - 50. Abstracts and programme of the 23rd international Baltic conference on the history of science. Riga: 2008.108 p.

198. Salaks J. The long time director of the Museum Karlis Eriks Arons (19332005), a born profesor.//XXIII, p. 42. 
199. Stradiņš J., Cēbere D. The Pauls Stradiņš Museum of history of medicine as part of the Latvian Academy of sciences (1946-1952).//XXIII, p. 43, 44.

200. Мирский М. Б. Профессор П. И. Страдынь - воспитанник российской хирургической школы.//XXIII, с. 44.

201. Vìksna A. The Latvian medical history in Baltic science history conferences: 1958-2006//XXIII, p. 46.

202. Bērziña E., M. Pozemkovska M. The 50-year history of the Pauls Stradiňš Museum of the history of medicine.//XXIII, p. 47.

203. Salaks J. The international contacts of the Pauls Stradinšs Museum of the history of medicine.//XXIII, p. 48.

204. Siudikas V., Mekas T., Šimantiene Z. Cooperation between the Museum of history of Lithuanian medicine and pharmacy and Pauls Stradiñ š Museum of the history of medicine.//XXIII, p. 49.

205. Lõvi-Kalnin M., Vỉksna A. Victor Kalnin and Baltic conferences on the history of science.//XXIII, p. 49, 50.

206. Felder B.M. Hereditary hygiene - race, nation and psychiatry in Latvia 19371944.//XXIII, p. 52.

207. Duplenko Y.K., Kochubey N.V. Development of ophthalmology in Ukraine and Latvia in the first quarter of XX century: parallels and intersections.// XXIII, p. 52-53.

208. Lilleorg J., Tankler H., Hinrikus T., Raal A. Pharmacy students from the Baltic provinces (Estonia, Livonia, Kurland) at the University of Tartu in 1892-1905.//XXIII, p. 53.

209. Kuznecovs V. Regulations of the Insane asylum and House of correction in the Riga Citadel (1787-1823).//XXIII, p. 55, 56.

210. Grāvere R. The development of anthropology as a field of academic study in Latvia in the first half of the 20th century.//XXIII, p. 60.

211. Vasylyev K.K. From the history of organization of higher medical school in Latvia: professor Georgy Yaveyn (1863-1920).//XXIII, p. 64.

212. Vasylyev J.K., Yarova O. Native of Latvia professor Bronislav Fortunatovich Verigo (1860-1925) and his activities in the society of Odessa physicians.// XXIII, p. 64. 


\section{The Latvian medical history in Baltic science history conferences: 1958-2008 (Summary)}

\section{By Arnis Vīksna}

Summarized abstract of conferences, but about first two conferences - summarized information by programmme of conferences. In total in 23 Baltic science history conferences are read up (are declared) 212 reports about of Latvian medical history, that is I -3 , II -2 , III -6 , IV $-11, \mathrm{~V}-4$, VI -11 , VII -12 , VIII -5 , IX - 9, X - 3, XI - 11, XII - 14, XIII - 3, XIV - 18, XV - 16, XVI - 6, XVII - 5, XVIII - 23, XIX - 5, XX - 6, XXI - 16, XXII - 8, XXIII - 15 abstracts. Them have prepared 121 author: K. Arons (10 abstracts), M. Baltiņš (5), E. Bērzin̨a (5), M. Blumberga (6), V. Derums (8), A. Dirbe (9), F. Grigorašs (7), J. Jākobsons (10), R. Kukaine (7), R. Lindberga (4), S. Magiḷnickis (4), A. Miltinšs (11), V. Miltiņš (4), M. Pozemkovska (Anže) (5), V. Pundure (5), J. Salaks (4), J. Stradiňš (6), M. Suhodrev (4), K. G. Vasilyev (7), K. K. Vasilyev (4), A. Viksna (33), and other.

For paleopathology are devoted 7 reports (V. Derums), for latvian folk medicine -6 (K. Arons, Ā. Karnups, A. Zviedre), for medicine in feudalism 5 (A. Dirbe, S. Kuze, A. Zviedre, and other), for medicine in capitalism - 8 (F. Grigorash, K. G. Vasilyev, A. Vìksna, and other), for soviet medicine and public health - 5 (F. Grigorash, V. Kaneps, and other). From medical disciplines in the centre of attention to scientists has involved history of surgery - 11 (A. Bieziņ̌š, and other) abstracts, dermatovenerology - 11 (A. Miltiņš, V. Miltiņš) abstracts, microbiology - 6 (J. Jākobsons, R. Kukaine) abstracts, oftalmology - 7 (S. Magilninickis, and other) abstracts, anatomy - 6 (R. Lindberga, V. Pundure, and other) abstracts, internal medicine - 4 (I. Lazovskis, and other) abstracts, psychiatry - 6 (I. Eglitis, V. Kuzņecovs, and other) abstracts, radiology - 3 (J. Lediņš, J. Nemiro) abstracts.

For Latvian higher medical education are devoted 13 reports (K. Arons, M. Baltiňš, M. L,ebedkova, U. Vikmanis, A. Vỉksna, and other), for epidemic history -4 (K. G. Vasiljevs, and other).

From medical disciplinary in the centre of attention are devoted to Pauls Stradinš Museum of the History of Medicine, whom are devoted 20 reports (E. Bērziña, H. Hanzena, M. L,ebedkova, and other), thereafter Riga hospital No. 1-7 reports, and Riga Military hospital - 2 reports.

From prominent persons more reports are devoted to P. Stradinšs (12), there after O. Huhn (5), A. Kirhenšteins (4), A. Bieziņš (3), J. Alksnis (2), G. Backmann (2), P. Snikers (2), and other.

The medical scientific communications of interstate and intermediate establishment of higher education are considered on 16 messages, it is more about 
University Dorpat/Tartu and Latvia (A. Vìksna, and another), after that university Vilnius and Moscow, Military medical academy of Petersburg.

In 9 reports are considered questions of medical historiography and in 3 reports - medical memorials (A. Vìksna, and other).

The conferences were opportunity incoming of new vigour in medical history researches and those advanced exchange of experience and collegiate relations between researchers. Are not absolutely considered methodical questions, and are not realized great interstate cooperation projects. Still positive ambience are remain, and that aid in daily work of each researcher.

\section{Arnis Vìksna,}

Latvijas Universitātes Medicīnas fakultāte

Šarlotes iela 1a, Rīga, LV 1001

arnis.viksna@lu.lv 